\title{
Dung Beetle Assemblage Structure in Tswalu Kalahari Reserve: Responses to a Mosaic of Landscape Types, Vegetation Communities, and Dung Types
}

\author{
ADRIAN L. V. DAVIS, ${ }^{1}$ CLARKE H. SCHOLTZ, UTE KRYGER, CHRISTIAN M. DESCHODT, \\ AND WERNER P. STRÜMPHER
}

Scarab Research Unit, Department of Zoology and Entomology, University of Pretoria, Lynnwood Rd., Pretoria 0002 , South Africa

\begin{abstract}
Environ. Entomol. 39(3): 811-820 (2010); DOI: 10.1603/EN09256
ABSTRACT Tswalu Kalahari Reserve is a private game reserve covering $1,020 \mathrm{~km}^{2}$ in the Northern Cape, South Africa. It has been created from a number of reclaimed farms and restocked with large indigenous mammals. Two surveys were conducted to inventory the dung beetle fauna (Coleoptera: Scarabaeidae: Scarabaeinae) and determine their spatial patterns and food type associations. The spatial survey used pig dung-baited pitfall traps to examine dung beetle distribution across three main landscape types (plains, dunes, hills) comprising six principal vegetation communities. The food study examined their relative associations with carrion and four different dung types within a single vegetation community. A total of 70 species was recorded. Because the food association study was spatially restricted and conducted under drought conditions, abundance and species richness (47 species) were much lower than in the spatial study (64 species), which was conducted after substantial rainfall. Principal spatial differences in species abundance structure of assemblages were between the sandy southwest plains and dunes; the sandy northern dune fields and plains; and the rocky hills. Forty species analyzed in the food association study showed clear distributional biases to carrion or the dung of elephant (monogastric herbivore), pig (omnivore), cattle and sheep (ruminant herbivores), or pig and cattle. The results (1) show how dung beetle assemblage structure is locally diversified across the heterogeneous landscape of the reserve and (2) indicate how the different dung types dropped by a diverse assemblage of indigenous mammals may variously favor different species of dung beetles.
\end{abstract}

KEY WORDS assemblage structure, dung, Kalahari, landscape, Tswalu

Dung beetle distribution patterns across spatial gradients are a response to various interacting factors. These include topography and climate (Kirk and Ridsdill-Smith 1986, Davis and Dewhurst 1993, Davis 1997), edaphic characteristics and vegetative physiognomy (Nealis 1977, Cambefort 1982, Davis 1996), dung type (Fincher et al. 1970, Davis 1994, Tshikae et al. 2008), dropping size (Peck and Howden 1984), and spatial frequency of droppings (Lobo et al. 2006). The relative influence of these factors varies both with spatial scale and the specific attributes of a geographical region, landscape, or locality (Davis et al. 2008).

In the open vegetation of the arid Northern Cape Province, South Africa, distribution patterns of scarabaeine beetles attracted to cattle and sheep dung are influenced by climatic and edaphic factors that interact to determine patterns shown at three spatial scales: regional, subregional, and habitat (Davis et al. 2008). At the regional scale, a major faunal

\footnotetext{
${ }^{1}$ Corresponding author, e-mail: adavis@zoology.up.ac.za.
}

division occurs across the interdigitized ecotone between the arid, often stony soils of the Nama Karoo that lies to the cooler southwest and the mostly deep sands of the less arid Kalahari to the northeast. Within the defined study area (Davis et al. 2008), separation at the subregional scale (warmer/moister Kalahari, cooler Upper Karoo, arid Bushmanland Karoo, and stony karoo patches or arid outlier Kalahari dunes along the Orange River valley) was influenced primarily by climatic patterns, either annual temperature or annual rainfall. Separation at local or habitat scale (13 divisions) was influenced primarily by edaphic factors, particularly stony versus deep soils, although soil grain size, ranging from sand to clay, may also be highly influential (Nealis 1977, Doube 1991, Davis 1996).

Understanding the factors that are important in determining regional and local distribution patterns is useful for conservation management. Therefore, this study examines patterns of dung beetle assemblage structure and their biogeographical composition within Tswalu Kalahari Reserve, which lies in 


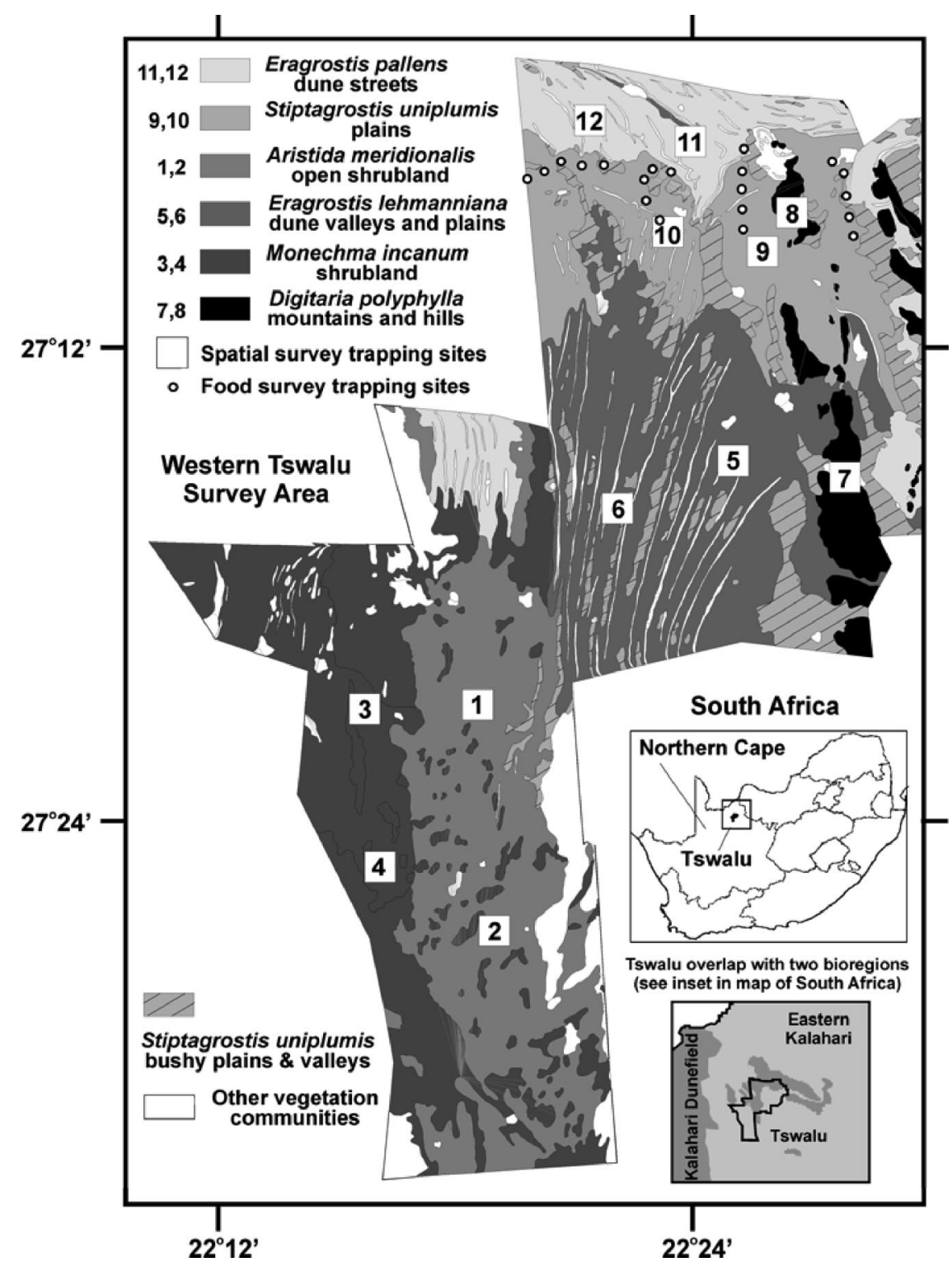

Fig. 1. Map showing (1) the location of Tswalu Kalahari Reserve in South Africa relative to two bioregions (Mucina and Rutherford 2006); (2) the principal vegetation communities in the western part of the reserve (Van Rooyen et al. 2005); and (3) the location of study sites for the spatial (squares numbered 1-12) and food surveys (20 small circles each representing four traps) for dung beetles.

the southwest Kalahari at the moister eastern edge of the region studied by Davis et al. (2008). The owners of Tswalu support various research projects to provide inventories of the fauna and flora and to assist in conservation management. This includes this study (Tswalu conservation project 2009) that provides an inventory of the dung beetle fauna on different food types and determines to what extent assemblage structure on pig dung is influenced by factors at regional biogeographical, landscape, and local vegetation community scales of spatial organization. Its main focus is on spatial patterns that descend to a finer-grained scale than those analyzed by Davis et al. (2008).

\section{Materials and Methods}

Study Area and Study Sites. Tswalu Kalahari Reserve was established in 1995 and is a private game reserve comprising $1,020 \mathrm{~km}^{2}$ (102,000 ha) situated in the northeast of Northern Cape Province, South Africa between latitudes $27^{\circ} 04^{\prime} \mathrm{S}$ to $27^{\circ} 33^{\prime} \mathrm{S}$ and longitudes $22^{\circ} 10^{\prime} \mathrm{E}$ to $22^{\circ} 36^{\prime} \mathrm{E}$ (Fig. 1). It ranges in altitude from $1,020 \mathrm{~m}$ on the plains to $1,586 \mathrm{~m}$ on the highest 
mountain peak and is fairly arid, receiving an average of $286-318 \mathrm{~mm}$ of rain per year over 5 by $5-\mathrm{km}$ polygons around the study sites, $76 \%$ of which falls from mid- to late summer between December and April.

Tswalu was created from a number of reclaimed farms and returned, as far as possible, to its former natural state by removing most farm developments and by restocking it with large indigenous mammals that formerly occurred either locally or in adjoining savanna regions. The 75 mammal species now in the reserve provide the full range of dung types present in savanna regions, including large, coarse-fibered droppings of monogastric herbivores (e.g., desert black rhinoceros, Burchell's zebra); large pads (African buffalo) or pellets (e.g., black and blue wildebeest, eland, gemsbok) of ruminant herbivores; and small, strongsmelling droppings of carnivores (e.g., lion) or omnivores (e.g., Chacma baboon).

The conserved landscape is geomorphologically and ecologically heterogeneous. It comprises rocky mountains, sandy plains, and fields of parallel dunes. These fall within two bioregions and five vegetation units (Mucina and Rutherford 2006), which include from 12 to 17 vegetation communities (Van Rooyen et al. 2005) on mostly sandy soils.

Tswalu is centered within the Eastern Kalahari Bioregion, but the northern part extends into an outlier patch of the Kalahari Dunefield Bioregion (Fig. 1). The included vegetation units comprise the northern tip of the Koranna Langeberg Mountain Bushveld with Gordonia Duneveld to the north, Gordonia Plains Shrubveld to the west, Olifantshoek Plains Thornveld close to the mountains both to the east and west, and Kathu Bushveld to the east. The latter two units remain unsampled for dung beetles.

The study area for dung beetles was restricted to the western part of Tswalu westward from the northsouth trending mountain range (Korannaberg) that bisects the reserve (Fig. 1). Study sites were selected according to a detailed vegetation classification of the reserve (Van Rooyen et al. 2005) that was defined at a finer-grained scale than the classification of Mucina and Rutherford (2006). It identified 17 plant communities ( 5 closely related) on the basis of diagnostic shrub or grass indicator species. A total of 12 of these communities were mapped (Fig. 1). Five covered a combined area of only $13.8 \%$ of the reserve and were not sampled for dung beetles. A sixth plant community was also not sampled for dung beetles as it occurred primarily in scattered patches despite amounting to an appreciable area of the reserve (15.6\% of Stiptagrostic uniplumis bushy plains and valleys). Dung beetle samples were taken only from the remaining six vegetation communities that occurred in large blocks and covered the greatest proportion of the reserve $(70.6 \%)$. These were defined either from diagnostic species or from distinctive species groupings (Van Rooyen et al. 2005 ). They comprised two communities centered on the northern or west-central dune field, three on the western plains, and one on the eastern mountains (Fig. 1). Brief descriptions of each concentrate primarily on edaphic characteristics and vegetative physiognomy, which are important determinants of dung beetle distribution (Doube 1991, Davis 1996), unlike plant species composition. More detailed data on geology, soils, characteristic plant species, veld condition, and recommended stocking rates may be obtained from van Rooyen et al. (2005).

Of the two main vegetation communities on the well-drained, aeolian, red sands of the Gordonia Duneveld (Mucina and Rutherford 2006), Eragrostis pallens dune streets occurred on the plains in the north and northwest and covered 13,003 ha comprising $14.8 \%$ of the reserve (study sites 11 and $12 ; 27.127^{\circ} \mathrm{S}$, $22.393^{\circ} \mathrm{E}$ or $27.123^{\circ} \mathrm{S}, 22.360^{\circ} \mathrm{E}$ ), whereas Eragrostis lehmanniana dune valleys and plains were centered on dune streets in the central west and covered $11,486 \mathrm{ha}$, comprising $13.1 \%$ of the reserve (study sites 5 and 6 ; $27.248^{\circ} \mathrm{S}, 22.417^{\circ} \mathrm{E}$ or $27.271^{\circ} \mathrm{S}, 22.367^{\circ} \mathrm{E}$ ). Both communities were characterized by open grassland with scattered trees and shrubs not exceeding $17 \%$ of the cover. However, typical dune grasses were conspicuously absent from the E. lehmanniana dune valleys and plains (Van Rooyen et al. 2005).

In Tswalu, the Gordonia plains shrubveld (Mucina and Rutherford 2006) mainly comprises aeolian surface sand and dunes that support three main vegetation communities (Fig. 1), comprising Stipagrostis uniplumis plains on poorly structured red soils in the north and Monechma incanum shrubveld plus Aristida meridionalis open shrubveld on red and yellow, welldrained sandy soils to the southwest. The S. uniplumis plains cover 8,794 ha, comprising $10 \%$ of the reserve (study sites 9 and $10 ; 27.169^{\circ} \mathrm{S}, 22.427^{\circ} \mathrm{E}$ or $27.153^{\circ} \mathrm{S}$, $22.397^{\circ} \mathrm{E}$ ). They are characterized by open grassland with scattered trees and shrubs not exceeding $14 \%$ of the cover. The A. meridionalis open shrubveld occurs on low dunes and deep sandy plains in the east of the southwest section of Tswalu. It covers 14,792 ha, comprising $16.9 \%$ of the reserve (study sites 1 and $2 ; 27.351^{\circ}$ $\mathrm{S}, 22.310^{\circ} \mathrm{E}$ or $27.308^{\circ} \mathrm{S}, 22.309^{\circ} \mathrm{E}$ ). Like most of the other vegetation communities, it is also characterized by open grassland with scattered trees and shrubs not exceeding $17 \%$ of the cover. The two varieties of the M. incanum shrubveld cover 9,048 ha on plains, dune streets, and depressions and comprise $10.3 \%$ of the reserve (study sites 3 and $4 ; 27.353^{\circ} \mathrm{S}, 22.262^{\circ} \mathrm{E}$ or $27.313^{\circ} \mathrm{S}, 22.231^{\circ} \mathrm{E}$ ). In contrast to the other main vegetation communities of Tswalu, it is characterized by dense shrubland, amounting to $35.1 \%$ of the cover, with a further $3.1 \%$ comprising tree cover. Many scattered patches of this shrubland also occur as inclusions within the adjoining Aristida meridionalis open shrubveld.

In Tswalu, the Koranna Langeberg Mountain Bushveld (Mucina and Rutherford 2006) is represented on the scattered rocky hills of the northern Korannaberg (Fig. 1). These hills have very limited soil cover and support two varieties of a vegetation community described as Croton gratissimus-Digitaria polyphylla hills and mountains. These occur in areas of differing proportional rock cover and comprise a combined total of 4,787 ha, amounting to $5.5 \%$ of the reserve (study sites 7 and $8 ; 27.253^{\circ} \mathrm{S}, 22.465^{\circ} \mathrm{E}$ or $27.139^{\circ} \mathrm{S}, 22.441^{\circ} \mathrm{E}$ ). On 
average, nonvegetated rocks cover $\approx 59.1 \%$ of the area, rising locally to $70-90 \%$, whereas grasses $(22.0 \%)$ and shrubs $(18.9 \%)$ showed similar but low average cover densities with trees being very scarce.

Sampling Methods and Spatial Patterns. In each of the six selected vegetation communities, two study sites were selected well within the boundaries of each block of vegetation (Fig. 1). Two pitfall traps were placed $50 \mathrm{~m}$ apart at each site. These comprised 5-liter plastic buckets (top diameter: $23 \mathrm{~cm}$, depth: $17.5 \mathrm{~cm}$ ) sunk into the soil to the level of the rims. Trapping was conducted in late summer 2008 soon after substantial rainfall, which fell generally across the reserve on 13-15 January (up to $110 \mathrm{~mm}$ ) and, thereafter, more sporadically across the reserve, most recently on 4 and 8 February (up to $28 \mathrm{~mm}$ ), just before trapping. On each of two consecutive 24 -h sampling occasions, the traps were baited with $\approx 250 \mathrm{ml}$ of cloth-wrapped pig dung supported over the center of each trap by two strong wires. Baiting started during late afternoon on 11 February. Traps were rebaited at 12-h intervals to present fresh baits to both day and night-flying species until early morning on 13 February. The catches were immobilized, using a little water and detergent in the base of each trap. They were removed and stored in $70 \%$ alcohol during the late afternoons of 12 and 13 February at the end of each 24-h sampling occasion. This provided 48 separate samples in total ( 6 vegetation communities $\times 2$ study sites $\times 2$ traps $\times 2 \mathrm{~d}$ ), 8 from each vegetation community.

Sampling Methods and Food Type Associations. Four well-separated 5 by 4 grids of 5-liter pitfall traps were placed in the north of Tswalu across the $S$. uniplumis plains (Fig. 1). Each grid was comprised of five lines of traps at $1-\mathrm{km}$ intervals with the four traps along each line separated by $50 \mathrm{~m}$. During trapping, each line of four traps was baited with the same bait type, but the five lines in each grid were baited with five different bait types that were cloth-wrapped and supported over each trap on two strong wires. These comprised $\approx 100 \mathrm{ml}$ of carrion (chicken livers) or $\approx 250 \mathrm{ml}$ of pig, cattle, sheep, or elephant dung. Trapping was conducted in late summer 2007 from 23 to 25 February. This period coincided with drought conditions because there had been no general rain over the reserve since 2 November 2006 ( $\leq 19 \mathrm{~mm}$ ). Rain did fall on 25 and 29 January (up to $30 \mathrm{~mm}$ ), a month before trapping, but only beyond the Korannaberg in the eastern part of the reserve to the east of the study area. There was no rain whatsoever recorded during February. Over the two 24-h trapping periods, fresh baits were placed on the traps in the early morning at the beginning of each period, and catches were removed at the end of each period. Although this design provided 160 separate samples in total (4 grids of traps $\times 5$ trap lines $\times 4$ traps per line $\times 2 \mathrm{~d}$ ) amounting to 32 samples per bait type, in practice, six carrion, three pig, four cattle, and one sheep sample were lost because of disturbance by animals.

Data Analysis. Species richness estimators contained in EstimateS v.7.50 (Colwell 2005) were used to predict whether the observed Tswalu species inven- tory was relatively complete. These tests were conducted on the spatial survey data both for the entire reserve ( 44 samples with 4 deleted: 2 from site 5 and 2 from site 7) and for each of the six surveyed vegetation communities ( 8 or 6 samples each). Values yielded by four estimators, abundance-based coverage estimator (ACE), incidence-based coverage estimator (ICE), Chaol, and Chao2, were used to calculate mean proportions and SDs of observed compared with predicted values of species richness.

A substantial data set was yielded by the spatial study because it was conducted under very moist conditions. These data were analyzed to examine relative differences in dung beetle assemblage structure between landscape types, vegetation communities, trapping sites, and traps. The data for days 1 and 2 were combined to produce a 64 by 24 raw data matrix that comprised mean abundances per trap for 64 species $X$ 6 vegetation communities $\times 2$ study sites $\times 2$ traps at each site. As mean abundances showed a wide range in magnitude, the data matrix was fourth root transformed. Nonparametric multidimensional scaling (NMDS) was conducted on a correlation matrix for species abundance across the 24 spatial variables using Statistica v.7 (StatSoft 2004). On the ordination plot derived from this analysis, a minimum spanning tree was fitted to the data points based on an analysis of the distance matrix using the Kruskal algorithm contained in the computer package Arlequin v.3.1 (Excoffier et al. 2006).

Because the food association study was conducted under drought conditions, most species were recorded in low density, and many occurred only sporadically. Therefore, the species data were contracted to mean numbers per trap for each bait type to minimize noise. After deletion of seven species sampled in very low numbers $(<0.12$ per trap), the raw data matrix comprised mean abundances for 40 species $\times 5$ bait types. NMDS was conducted on a correlation matrix for bait association patterns of these 40 species using Statistica v.7 (StatSoft 2004). A cross-tabulation table and a goodness of fit test (Pearson's $\chi^{2}$ ) were used to determine whether there were significant differences between proportional bait-type associations shown by five groups of species defined from the NMDS ordination plot.

An analysis of the biogeographical composition of the dung beetle fauna recorded in the Northern Cape by Davis et al. (2008) was used to biogeographically classify the species recorded in this study. Category 1 comprised species with distributions centered in the arid southwest of southern Africa. Category 2 comprised species centered on the deep sands of the Kalahari Basin in central southern Africa, either widespread or restricted to the southwest of this region. Category 3 comprised species centered in the savannas to the north and northeast of the Kalahari. The other categories comprised (4) species widespread in Southern Africa, (5) those centered in the uplands of the eastern Highveld of South Africa, and (6) unclassified species. The proportional biogeographical composition of species abundance was determined for 
each of the six main vegetation communities in Tswalu. Cross-tabulation tables with goodness of fit tests (Pearson's $\chi^{2}$ ) were used to determine whether there were significant differences between the biogeographical compositions of different vegetation communities.

\section{Results}

A total of 70 species of dung beetles were recorded in Tswalu. The food association study was conducted under drought conditions in a single vegetation community and yielded a much lower species richness (47) and total abundance $(65,419)$ than the spatial study $(64$ species, total abundance $=124,410)$ that was conducted in six vegetation communities after substantial rainfall (Tables 1 and 2). Although trapping intensity in the food study, using five bait types, was more than three times greater than in the spatial study, using a single bait type, mean abundance per trap was much lower in the food study (448.1) than in the spatial study $(2,827.5)$. Different bait types attract different numbers of beetles (Table 2). However, on the $S$. uniplumis plains, species abundance in pig dung-baited traps was clearly much lower during drought (food study: 29 traps, 33 species, mean abundance per trap $=735.3$; spatial study: 8 traps, 48 species, mean abundance per trap $=2,615.1$ ).

A comparison between observed and predicted numbers of species suggests that high proportions of the taxa present in the reserve and vegetation communities (Table 3) were recorded by the two surveys. In the vegetation communities, observed species totals vary from 38 on the rocky hills, to $41-43$ on the dunes, to $42-48$ on the plains. Although similar observed numbers of species were recorded in the spatial (48) and food association studies (47) on the S. uniplumis plains, 13 were not recorded in the food study, and 6 were not trapped in the spatial study. It is noteworthy that all but one of these six species was trapped on bait types other than pig dung (Table 2). Totals of 54 $(48+6)$ or 60 species $(47+13)$ tally well with the upper and lower deviations on predictions of total species richness on the S. uniplumis plains (Table 3). Similarly, a total of 70 species $(64+6)$ tallies well with the lower limit of the wide deviation in total species richness predicted for the reserve from results for the spatial survey.

Figure 2 shows four clear clusters of species with regard to bait type association. One of these clusters is subdivided to produce five clusters in total. These divisions are supported by bar diagrams showing the mean bait association of each cluster. These results indicate various significantly different patterns of proportional bias (five by five cross-tabulation: Pearson's $\left.\chi^{2}=465.69, \mathrm{df}=16, P<0.001\right):(1)$ to carrion represented by rotted chicken livers ( 2 species); (2) to coarse-fibered monogastric herbivore dung represented by that of elephant ( 5 species); (3) to pads or pellets of ruminant herbivores represented by cattle and sheep dung (8 species); (4) to omnivore dung represented by that of pig (11 species); or (5) mixed responses with strong attraction to both pig and cattle dung (14 species).

Figure 3 shows some clear patterns of dissimilarity between the dung beetle assemblages recorded at different places across the three landscape types within Tswalu (hills, plains, and dune fields). The widely separated cluster comprising the assemblages from sites 7 and 8 is consistent with the quite different faunal structure on the rocky hills (Table 1). However, the other two proximal clusters comprised sandy southwest or northern sites that showed some inconsistencies with the landscape/vegetation community classification. Although sites 1-4 on the southwest plains were both clustered and linked together on the ordination plot, they were also closely clustered and linked to the assemblages of site 6 originating from the southwest of the central dune field (Fig. 1). Overall, this southwest cluster was linked to the assemblages of site 5 that originate from the northeast of the central dune field and were included in the cluster comprising the remaining dune field and plains sites in the north of Tswalu. The dune field sites, 5,11 , and 12 , were clustered in a fairly diffuse manner but were all linked by the minimum spanning tree, which linked their part of the northern cluster to that comprising the linked northern plains sites 9 and 10, which are geographically separated from the southwest plains by the central dune field. The northern plains sites were linked at great ordinal distance to sites 7 and 8 on the geographically nearby hills. Overall, for each site, data points for traps 1 and 2 were mostly fairly close to one another in ordinal space.

Biogeographical composition of the Tswalu dung beetle fauna was dominated by species showing distributional centers in three regions, southwest arid, Kalahari, and northeast savanna (Table 4). There were significant differences in proportional biogeographical composition between the six vegetation communities (three by six cross-tabulation: Pearson's $\chi^{2}=$ 134.996, $\mathrm{df}=10, P<0.001)$. In terms of relative abundance, assemblages on the hills were dominated by southwest arid elements, whereas the remainder of the vegetation communities were dominated by Kalahari and northeast savanna elements. On the plains and dunes, there was an overall trend to greater proportional Kalahari representation in the south and more equitable Kalahari and northeast savanna representation in the north (Table 4), although this was not significant (two by five cross-tabulation: Pearson's $\left.\chi^{2}=8.402, \mathrm{df}=4, P=0.078\right)$. This trend does not persist after the removal of data for the superabundant Kalahari centered species, Onthophagus sp. nr variegatus (Table 1) but is replaced by more localized patterns of imbalance with greater similarity between the north and south (Table 4; Pearson's $\chi^{2}=1.890$, $\mathrm{df}=4, P=0.756)$. Many individual species show no consistent north/south spatial trend and some, such as the northeast savanna centered Scarabaeus zambezianus, are more abundant in the southwest whereas others, such as the Kalahari centered Scarabaeus damarensis, are more abundant on the Kalahari dunes in the north (Table 1). 
Table 1. Abundance of 64 species of dung beetles recorded in the spatial survey of Tswalu Kalahari Reserve after substantial rainfall

\begin{tabular}{|c|c|c|c|c|c|c|}
\hline \multirow{3}{*}{ Species } & \multicolumn{6}{|c|}{ Mean no. per trap } \\
\hline & \multicolumn{2}{|c|}{ SW plains } & \multirow{2}{*}{$\begin{array}{l}\text { Mid dunes } \\
\text { (Sites 5,6) }\end{array}$} & \multirow{2}{*}{$\begin{array}{c}\text { Hills } \\
(\text { Sites } 7,8)\end{array}$} & \multirow{2}{*}{$\begin{array}{c}\text { N plains } \\
(\text { Sites } 9,10)\end{array}$} & \multirow{2}{*}{$\begin{array}{c}\mathrm{N} \text { dunes } \\
(\text { Sites } 11,12)\end{array}$} \\
\hline & (Sites 1,2) & (Sites 3,4) & & & & \\
\hline Pachylomera femoralis (Kirby) ${ }^{3}$ & 26.3 & 20.3 & 33.8 & 22.9 & 47.8 & 45.6 \\
\hline Pachylomera opacus van Lansberge ${ }^{2}$ & 0.1 & 0.3 & 0.0 & 0.0 & 0.1 & 0.3 \\
\hline Scarabaeus (Kheper) lamarcki Macleay ${ }^{3}$ & 2.9 & 2.9 & 0.7 & 1.3 & 2.4 & 0.8 \\
\hline Scarabaeus (Scarabaeus) ambiguus Boheman ${ }^{6}$ & 0.0 & 0.0 & 0.0 & 2.0 & 0.0 & 0.0 \\
\hline Scarabaeus (Scarabaeus) costatus Wiedemann ${ }^{1}$ & 0.0 & 0.1 & 0.1 & 0.0 & 1.0 & 2.8 \\
\hline Scarabaeus (Scarabaeus) proboscideus (Guérin) ${ }^{2}$ & 3.1 & 2.0 & 0.3 & 0.0 & 0.3 & 0.6 \\
\hline Scarabaeus (Scarabaeus) satyrus Boheman ${ }^{2}$ & 0.0 & 0.4 & 0.0 & 0.3 & 0.0 & 0.0 \\
\hline Scarabaeus (Scarabaeus) zambesianus Péringuey ${ }^{3}$ & 15.4 & 9.3 & 5.2 & 3.1 & 4.0 & 2.0 \\
\hline Scarabaeus (Scarabeolus) anderseni Waterhouse ${ }^{2}$ & 0.0 & 0.3 & 0.0 & 0.0 & 0.3 & 0.0 \\
\hline Scarabaeus (Scarabeolus) bohemani Harold $^{6}$ & 0.0 & 0.0 & 0.0 & 0.9 & 0.0 & 0.0 \\
\hline Scarabaeus (Scarabeolus) damarensis Janssens ${ }^{2}$ & 9.5 & 3.6 & 5.9 & 0.0 & 8.9 & 21.9 \\
\hline Scarabaeus (Scarabeolus) flavicornis Boheman ${ }^{2}$ & 33.1 & 15.6 & 36.9 & 4.1 & 19.4 & 37.1 \\
\hline Scarabaeus (Scarabeolus) inoportunus Ferreira ${ }^{1}$ & 0.3 & 0.0 & 0.1 & 0.0 & 0.1 & 5.5 \\
\hline Scarabaeus (Scarabeolus) inquisitus Péringuey ${ }^{2}$ & 0.0 & 0.0 & 0.0 & 0.0 & 0.1 & 0.0 \\
\hline Scarabaeus (Scarabeolus) kochi Ferreira ${ }^{2}$ & 0.1 & 0.1 & 0.1 & 0.0 & 0.0 & 0.0 \\
\hline $\begin{array}{l}\text { Scarabaeus (Sceliages) granulatus (Forgie, } \\
\text { Grebennikov \& Scholtz) }\end{array}$ & 0.0 & 0.0 & 0.0 & 0.0 & 0.0 & 0.1 \\
\hline Allogymnopleurus thalassinus $\mathrm{Klug}^{3}$ & 57.4 & 64.6 & 121.8 & 25.3 & 204.1 & 62.0 \\
\hline Gymnopleurus aenescens Wiedemann ${ }^{3}$ & 10.3 & 4.1 & 6.6 & 0.4 & 14.9 & 6.4 \\
\hline Gymnopleurus humanus Macleay ${ }^{1}$ & 2.0 & 0.3 & 2.0 & 1012.8 & 51.9 & 8.1 \\
\hline Neosisyphus macroruber (Paschalidis) ${ }^{5}$ & 0.0 & 0.3 & 0.9 & 11.3 & 0.4 & 0.4 \\
\hline Heliocopris japetus $\mathrm{Klug}^{6}$ & 0.0 & 0.1 & 0.0 & 0.0 & 0.0 & 0.0 \\
\hline Pedaria sp. $\mathrm{a}^{2}$ & 0.1 & 0.1 & 0.0 & 0.0 & 0.3 & 0.0 \\
\hline Pedaria cuprascens Harold $^{4}$ & 0.0 & 0.0 & 0.0 & 0.3 & 0.0 & 0.0 \\
\hline Pycnopanelus krikkeni Cambefort ${ }^{1}$ & 0.4 & 0.1 & 0.0 & 0.0 & 0.3 & 0.1 \\
\hline Catharsius calaharicus Kolbe $^{2}$ & 4.6 & 2.5 & 1.5 & 0.3 & 8.8 & 3.9 \\
\hline Catharsius melancholicus Boheman ${ }^{3}$ & 5.5 & 1.5 & 1.7 & 0.4 & 1.5 & 4.5 \\
\hline Metacatharsius dentinum Ferreira ${ }^{2}$ & 1.0 & 0.4 & 0.2 & 0.0 & 0.1 & 0.8 \\
\hline Metacatharsius exiguiformis Ferreira $^{2}$ & 16.9 & 29.6 & 7.9 & 0.3 & 9.8 & 21.6 \\
\hline Metacatharsius latifrons (Harold) ${ }^{2}$ & 0.0 & 0.0 & 0.0 & 0.0 & 0.1 & 0.0 \\
\hline Metacatharsius marani Balthasar ${ }^{1}$ & 0.0 & 0.0 & 0.0 & 0.7 & 0.1 & 0.0 \\
\hline Metacatharsius pumilioniformis Ferreira $^{1}$ & 0.3 & 0.0 & 0.0 & 0.1 & 0.4 & 1.6 \\
\hline Metacatharsius troglodytes (Boheman) ${ }^{3}$ & 0.4 & 0.0 & 0.0 & 0.0 & 0.1 & 1.8 \\
\hline Metacatharsius sp. $\mathrm{A}^{2}$ & 0.6 & 0.1 & 2.3 & 0.0 & 0.0 & 1.1 \\
\hline Cheironitis hoplosternus Harold ${ }^{5}$ & 0.3 & 0.1 & 0.5 & 0.3 & 0.0 & 0.0 \\
\hline Caccobius ferrugineus Fahraeus ${ }^{3}$ & 26.1 & 15.6 & 17.6 & 18.6 & 28.0 & 6.9 \\
\hline Caccobius nigritulus $\mathrm{Klug}^{3}$ & 2.5 & 5.8 & 0.2 & 0.7 & 2.8 & 4.9 \\
\hline Cleptocaccobius viridicollis (d'Orbigny) ${ }^{3}$ & 3.5 & 0.8 & 4.5 & 116.6 & 78.4 & 12.9 \\
\hline Euonthophagus sp. ${ }^{6}$ & 0.0 & 0.0 & 0.1 & 0.0 & 0.0 & 0.0 \\
\hline Onthophagus acutus d'Orbigny ${ }^{1}$ & 0.0 & 0.3 & 0.0 & 0.0 & 0.0 & 0.0 \\
\hline Onthophagus sp. $\mathrm{nr}$ bicavifrons ${ }^{6}$ & 0.0 & 1.9 & 0.0 & 0.0 & 0.0 & 0.0 \\
\hline Onthophagus cinctipennis Quedenfeldt ${ }^{6}$ & 0.0 & 0.0 & 0.0 & 0.0 & 0.1 & 0.0 \\
\hline Onthophagus flavimargo d'Orbigny ${ }^{2}$ & 22.6 & 87.8 & 6.5 & 52.3 & 20.3 & 6.6 \\
\hline Onthophagus pallidipennnis Fahraeus ${ }^{3}$ & 12.6 & 7.5 & 3.1 & 4.2 & 13.9 & 18.0 \\
\hline Onthophagus probus Péringuey ${ }^{1}$ & 77.0 & 65.5 & 281.3 & 20.3 & 101.4 & 5.8 \\
\hline Onthophagus sp. nr probus ${ }^{2}$ & 220.4 & 533.3 & 157.2 & 17.7 & 228.5 & 360.4 \\
\hline Onthophagus sp. nr pullus $(\mathrm{a})^{2}$ & 50.8 & 22.4 & 32.2 & 13.6 & 124.9 & 78.9 \\
\hline Onthophagus quadraticeps Harold $^{3}$ & 526.1 & 439.9 & 99.3 & 14.9 & 361.0 & 441.1 \\
\hline Onthophagus signatus Fahraeus ${ }^{3}$ & 389.1 & 248.8 & 446.3 & 113.5 & 477.6 & 386.8 \\
\hline Onthophagus semiflavus Boheman ${ }^{1}$ & 0.5 & 1.3 & 0.0 & 0.0 & 0.0 & 0.0 \\
\hline Onthophagus sp. nr variegatus ${ }^{2}$ & $1,484.9$ & $1,965.6$ & 667.0 & 757.7 & 545.4 & 191.8 \\
\hline Onthophagus verticalis Boheman ${ }^{3}$ & 0.0 & 0.0 & 0.0 & 0.0 & 0.6 & 0.0 \\
\hline Onthophagus sp. $\mathrm{A}^{1}$ & 9.5 & 11.8 & 14.9 & 0.1 & 4.9 & 2.1 \\
\hline Onthophagus sp. $\mathrm{B}^{2}$ & 7.1 & 4.4 & 15.6 & 1.3 & 10.8 & 43.9 \\
\hline Onthophagus sp. $\mathrm{F}^{1}$ & 0.4 & 0.0 & 0.1 & 0.0 & 0.5 & 0.5 \\
\hline Onthophagus sp. $\mathrm{G}^{1}$ & 0.0 & 0.0 & 2.0 & 810.2 & 1.4 & 0.1 \\
\hline Onthophagus sp. $\mathrm{K}^{2}$ & 74.3 & 136.0 & 155.7 & 3.2 & 45.0 & 84.0 \\
\hline Onthophagus sp. $\mathrm{L}^{6}$ & 0.0 & 0.0 & 0.0 & 0.3 & 0.0 & 0.0 \\
\hline Phalops dregei Harold ${ }^{6}$ & 0.0 & 0.0 & 0.0 & 1.3 & 0.0 & 0.1 \\
\hline Phalops rufosignatus van Lansberge ${ }^{2}$ & 391.0 & 269.3 & 184.4 & 111.6 & 121.1 & 13.8 \\
\hline Phalops wittei Harold $^{3}$ & 21.8 & 3.6 & 5.3 & 40.0 & 60.8 & 12.8 \\
\hline Proagoderus sapphirinus Fahraeus ${ }^{2}$ & 4.8 & 4.8 & 3.3 & 4.6 & 10.6 & 18.0 \\
\hline Drepanocerus patrizii Boucomont $^{6}$ & 0.0 & 0.0 & 0.0 & 0.0 & 0.1 & 0.0 \\
\hline Euoniticellus intermedius (Reiche) ${ }^{4}$ & 0.4 & 0.4 & 0.3 & 0.0 & 0.4 & 0.4 \\
\hline Oniticellus formosus Chevrolat ${ }^{4}$ & 0.0 & 0.0 & 0.1 & 0.0 & 0.0 & 0.0 \\
\hline Total mean abundance per trap & $3,515.6$ & $3,984.9$ & $2,325.5$ & $3,189.4$ & $2,615.1$ & $1,918.4$ \\
\hline
\end{tabular}

Superscripted numbers represent a biogeographical classification of distribution centres derived from Davis et al. $(2008): 1=$ southwest arid, $2=$ Kalahari, $3=$ Northeast savanna, $4=$ Widespread, $5=$ Upland (Highveld), $6=$ Unclassified. 
Table 2. Abundance of 47 species of dung beetles recorded in the food association survey of Tswalu Kalahari Reserve during drought conditions

\begin{tabular}{|c|c|c|c|c|c|c|}
\hline & \multirow{2}{*}{ Species } & \multicolumn{5}{|c|}{ Mean no. per trap attracted to carrion or each dung type } \\
\hline & & Carrion & Pig & Elephant & Cattle & Sheep \\
\hline 1 & Pachylomera femoralis (Kirby) & 0.14 & 0.55 & 0.19 & 0.21 & 0.06 \\
\hline 2 & Scarabaeus (Kheper) lamarcki Macleay & 0.00 & 0.04 & 0.00 & 0.00 & 0.00 \\
\hline$\overline{3}$ & Scarabaeus (Scarabaeus) proboscideus (Guérin) & 0.08 & 1.41 & 0.13 & 0.24 & 2.27 \\
\hline 4 & Scarabaeus (Scarabaeus) zambesianus Péringuey & 0.15 & 8.97 & 1.81 & 1.64 & 6.27 \\
\hline 5 & Scarabaeus (Scarabeolus) anderseni Waterhouse & 0.29 & 0.63 & 0.03 & 0.57 & 0.03 \\
\hline 6 & Scarabaeus (Scarabeolus) damarensis Janssens & 0.00 & 0.03 & 0.00 & 0.00 & 0.00 \\
\hline 7 & Scarabaeus (Scarabeolus) flavicornis Boheman & 2.05 & 5.29 & 0.22 & 1.46 & 0.00 \\
\hline 8 & Scarabaeus (Scarabeolus) kochi Ferreira & 0.00 & 0.00 & 0.00 & 0.03 & 0.00 \\
\hline 9 & Allogymnopleurus thalassinus Klug & 0.07 & 0.18 & 0.09 & 0.19 & 0.10 \\
\hline 10 & Gymnopleurus aenescens Wiedemann & 0.51 & 5.29 & 0.66 & 2.01 & 1.32 \\
\hline 11 & Gymnopleurus humanus Macleay & 0.00 & 0.00 & 0.00 & 0.04 & 0.07 \\
\hline 12 & Pedaria sp. a & 0.00 & 0.00 & 0.03 & 0.14 & 0.16 \\
\hline 13 & Catharsius calaharicus Kolbe & 0.00 & 0.03 & 0.16 & 0.00 & 0.00 \\
\hline 14 & Catharsius melancholicus Boheman & 0.21 & 0.03 & 0.03 & 0.03 & 0.00 \\
\hline 15 & Copris cornifrons Boheman & 0.00 & 0.00 & 0.16 & 0.00 & 0.00 \\
\hline 16 & Metacatharsius exiguiformis Ferreira & 0.00 & 0.93 & 0.34 & 3.10 & 2.80 \\
\hline 17 & Metacatharsius latifrons (Harold) & 0.00 & 0.00 & 0.03 & 0.07 & 0.06 \\
\hline 18 & Metacatharsius sp. A & 0.00 & 0.00 & 0.00 & 0.03 & 0.29 \\
\hline 19 & Cheironitis hoplosternus Harold & 0.00 & 0.04 & 0.00 & 0.00 & 0.00 \\
\hline 20 & Onitis deceptor Péringuey & 0.00 & 0.00 & 0.00 & 0.00 & 0.03 \\
\hline 21 & Caccobius cavatus d'Orbigny & 0.00 & 0.00 & 0.00 & 0.08 & 0.00 \\
\hline 22 & Caccobius ferrugineus Fahraeus & 0.36 & 3.50 & 0.91 & 1.24 & 0.92 \\
\hline 23 & Caccobius nigritulus Klug & 0.00 & 0.64 & 0.41 & 0.00 & 0.36 \\
\hline 24 & Cleptocaccobius viridicollis (d'Orbigny) & 0.00 & 0.08 & 0.03 & 0.04 & 0.06 \\
\hline 25 & Digitonthophagus gazella (Fabricius) & 0.00 & 0.00 & 0.03 & 0.00 & 0.03 \\
\hline 26 & Onthophagus sp. nr apiciosus & 0.00 & 0.06 & 0.00 & 0.00 & 0.00 \\
\hline 27 & Onthophagus sp. nr bicavifrons & 0.07 & 0.00 & 0.00 & 0.00 & 0.00 \\
\hline 28 & Onthophagus flavimargo d'Orbigny & 0.75 & 2.97 & 1.69 & 3.43 & 0.86 \\
\hline 29 & Onthophagus pallidipennnis Fahraeus & 0.00 & 0.23 & 0.25 & 0.37 & 0.69 \\
\hline 30 & Onthophagus probus Péringuey & 0.04 & 4.35 & 16.16 & 3.84 & 2.12 \\
\hline 31 & Onthophagus sp. nr probus & 0.32 & 89.08 & 28.91 & 22.63 & 20.54 \\
\hline 32 & Onthophagus sp. nr pullus (a) & 0.00 & 0.37 & 0.16 & 0.30 & 0.22 \\
\hline 33 & Onthophagus quadraticeps Harold & 0.14 & 43.28 & 9.22 & 10.29 & 9.29 \\
\hline 34 & Onthophagus ?rasipennis d'Orbigny & 0.00 & 0.00 & 0.00 & 0.00 & 8.56 \\
\hline 35 & Onthophagus signatus Fahraeus & 2.24 & 66.68 & 14.31 & 35.87 & 15.15 \\
\hline 36 & Onthophagus semiflavus Boheman & 0.00 & 5.84 & 0.06 & 0.07 & 0.25 \\
\hline 37 & Onthophagus sp. nr variegatus & 22.57 & 457.37 & 364.09 & 441.09 & 317.99 \\
\hline 38 & Onthophagus verticalis Boheman & 0.00 & 0.00 & 0.09 & 0.00 & 0.00 \\
\hline 39 & Onthophagus sp. A & 0.76 & 3.84 & 0.28 & 4.11 & 0.06 \\
\hline 40 & Onthophagus sp. B & 1.01 & 5.01 & 0.19 & 2.57 & 0.16 \\
\hline 41 & Onthophagus sp. G & 0.00 & 3.72 & 1.63 & 2.71 & 3.21 \\
\hline 42 & Onthophagus sp. K & 0.55 & 21.20 & 6.00 & 15.89 & 11.43 \\
\hline 43 & Phalops rufosignatus van Lansberge & 0.11 & 0.96 & 0.56 & 0.51 & 0.80 \\
\hline 44 & Phalops wittei Harold & 0.04 & 0.47 & 0.19 & 0.26 & 0.33 \\
\hline 45 & Proagoderus sapphirinus Fahraeus & 0.73 & 2.16 & 0.84 & 1.08 & 0.86 \\
\hline 46 & Euoniticellus intermedius (Reiche) & 0.00 & 0.00 & 0.03 & 0.25 & 0.20 \\
\hline \multirow{2}{*}{47} & Oniticellus formosus Chevrolat & 0.00 & 0.00 & 0.06 & 0.03 & 0.00 \\
\hline & All species & 33.19 & 735.26 & 449.97 & 556.43 & 407.58 \\
\hline
\end{tabular}

\section{Discussion}

Tswalu Kalahari Reserve has been designed to conserve a heterogeneous part of the landscape in the Northern Cape and to return it to a semblance of its

Table 3. Observed species richness, mean predicted total species richness (see Materials and Methods), and mean proportion of species observed in the spatial survey of Tswalu Kalahari Reserve and six vegetation communities

\begin{tabular}{|c|c|c|c|}
\hline \multirow[b]{2}{*}{ Sites } & \multicolumn{2}{|c|}{ No. species } & \multirow{2}{*}{$\begin{array}{c}\% \text { species } \\
(\text { Observed } \pm \mathrm{SD})\end{array}$} \\
\hline & Observed & $\begin{array}{l}\text { Predicted } \\
\pm \mathrm{SD}\end{array}$ & \\
\hline Entire reserve & 64 & $77.9 \pm 5.2$ & $82.5 \pm 5.2$ \\
\hline Sites 1, 2-plains & 42 & $43.5 \pm 0.5$ & $96.6 \pm 1.1$ \\
\hline Sites 3,4 -plains & 45 & $50.2 \pm 1.2$ & $89.7 \pm 2.1$ \\
\hline Sites 5,6-dunes & 41 & $46.1 \pm 0.8$ & $89.0 \pm 1.7$ \\
\hline Sites 7,8-hills & 38 & $42.8 \pm 1.4$ & $88.9 \pm 2.8$ \\
\hline Sites 9,10 -plains & 48 & $57.2 \pm 2.0$ & $84.0 \pm 3.0$ \\
\hline Sites 11,12 -dunes & 43 & $45.6 \pm 0.4$ & $94.2 \pm 0.9$ \\
\hline
\end{tabular}

former pristine state by removing most farm developments and reintroducing large indigenous mammals. Although its vegetation is classified as entirely comprising different units of the Kalahari Savanna flora (Mucina and Rutherford 2006), in terms of relative abundance, the mountain dung beetle assemblages of the Korannaberg are dominated by two species (Gymnoplerus humanus, Onthophagus sp. G) that Davis et al. (2008) recorded as dominant elements in many assemblages of the southwest arid centered, Nama Karoo, as well as on stony soils at the southwest edge of the Kalahari. In contrast, the assemblages on the plains and dunes of the reserve are indeed characterized by dominance of psammophilous dung beetle species with distributions centered in the Kalahari or the northeast Savanna. It is highly probable that spatial differences in proportional representation of these northeast Savanna and Kalahari elements are related to edge effects and localized factors within vegetation 


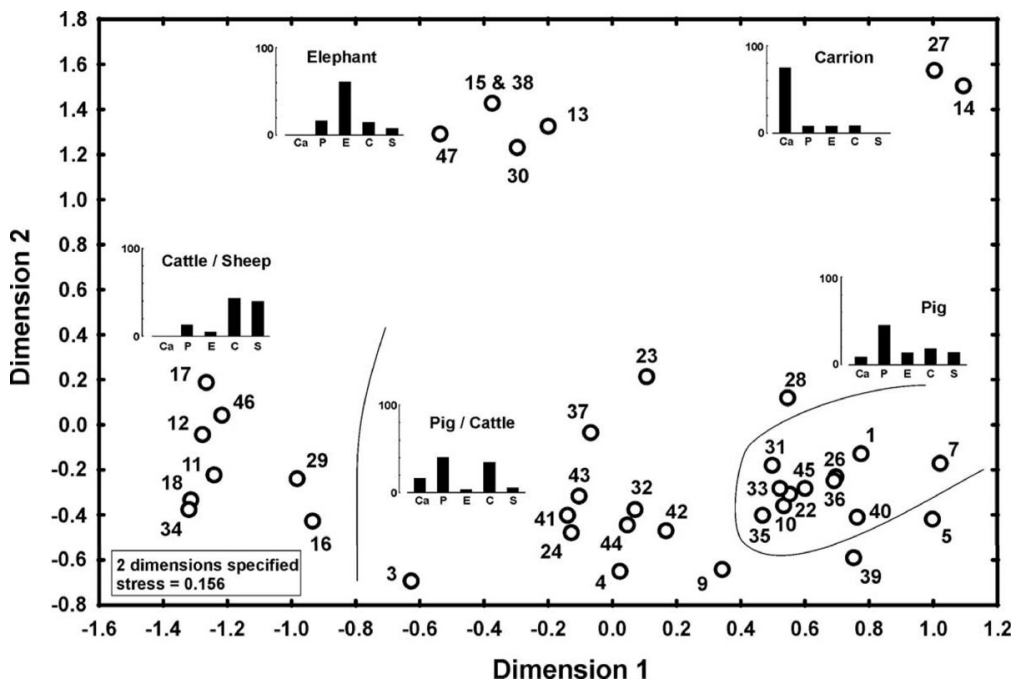

Fig. 2. MDS ordination plot showing statistical distances between the food associations of 40 species of dung beetles in Tswalu Kalahari Reserve and the average percentage occurrences of five species groups attracted to different dung (omnivore, $\mathrm{P}=$ pig; monogastric herbivore, $\mathrm{E}=$ elephant; ruminant herbivore, pads $\mathrm{C}=$ cattle, pellets $\mathrm{S}=\operatorname{sheep})$ or carrion baits $(\mathrm{Ca}=$ carrion) (see Table 2 for key to species code numbers).

communities rather than to any reserve-wide trend, although ordination indicated a structural difference between southwest and northern assemblages. A minor, average annual rainfall gradient from $298-318 \mathrm{~mm}$ in the north to $285-304 \mathrm{~mm}$ in the southwest is unlikely to be responsible for this result. However, relatively low species abundance recorded in the food study would certainly be primarily related to incidence of rainfall as species richness declines over time after precipitation (Davis 1995, 2002), and there had been none in Tswalu for some time before trapping. This claim is further supported by the results for pig dung- baited traps on the S. uniplumis plains that show much lower species abundance during drought compared with wet conditions.

Considered in its entirety, species richness of the Tswalu dung beetle fauna (70 species) is comparable to that recorded in the main block of the southwest Kalahari studied by Davis et al. (2008) (93 species). Of the 70 Tswalu species, 9 mostly uncommon species were not recorded in the study to the southwest. Of 32 species recorded in the southwest Kalahari but not in Tswalu, 17 were mostly recorded as rarities in a study with much greater collecting intensity than that in

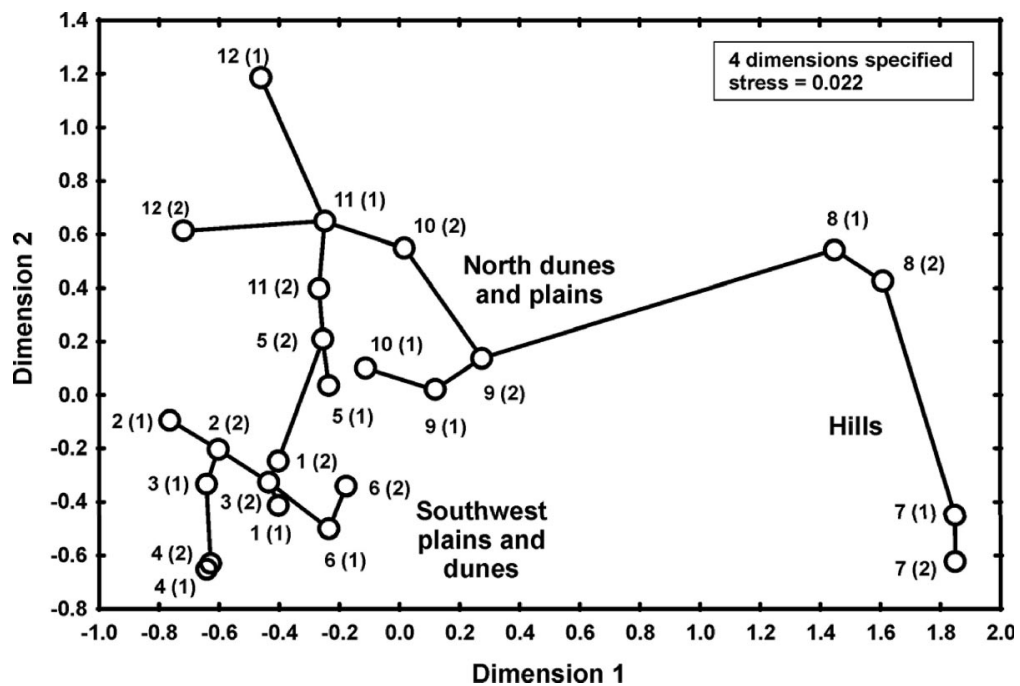

Fig. 3. MDS ordination plot and minimum spanning tree showing the statistical distances between mean species abundance structure of dung beetle assemblages at two sites in each of six principal vegetation communities in Tswalu Kalahari Reserve (the first numbers are the site number (1-12, see Fig. 1), and the numbers in brackets are the trap number at each site (1 or 2$)$. 
Table 4. Proportional biogeographical composition of dung beetle assemblages within each of six vegetation communities of Tswalu Kalahari Reserve (see Fig. 1 for key) with or without the inclusion of data for $O$. sp. nr variegatus

\begin{tabular}{|c|c|c|c|c|c|c|}
\hline \multirow{3}{*}{ Distribution centers } & \multicolumn{6}{|c|}{$\%$ abundance $^{a}$} \\
\hline & \multicolumn{2}{|c|}{ SW plains } & \multirow{2}{*}{$\begin{array}{l}\text { Mid dunes } \\
\text { (Sites 5,6) }\end{array}$} & \multirow{2}{*}{$\begin{array}{c}\text { Hills } \\
(\text { Sites 7, 8) }\end{array}$} & \multirow{2}{*}{$\begin{array}{c}\text { N plains } \\
(\text { Sites } 9,10)\end{array}$} & \multirow{2}{*}{$\begin{array}{c}\mathbf{N} \text { dunes } \\
(\text { Sites } 11,12)\end{array}$} \\
\hline & (Sites 1, 2) & (Sites 3, 4) & & & & \\
\hline Southwest arid & 2.6 & 2.0 & 12.9 & 58.0 & 6.2 & 1.3 \\
\hline Kalahari & 68.0 & 79.0 & 60.4 & 31.2 & 52.5 & 49.7 \\
\hline Northeast savanna & 29.3 & 19.0 & 26.5 & 10.6 & 41.2 & 48.8 \\
\hline Total percentage $^{b}$ & 99.9 & 100.0 & 98.9 & 99.8 & 99.9 & 99.8 \\
\hline \multicolumn{7}{|c|}{ After removal of data for $O$. sp. nr variegatus } \\
\hline Southwest arid & 4.4 & 3.9 & 18.1 & 76.2 & 7.8 & 1.4 \\
\hline Kalahari & 44.7 & 58.5 & 44.5 & 9.7 & 40.0 & 44.1 \\
\hline Northeast & 50.8 & 37.4 & 37.2 & 13.9 & 52.1 & 54.3 \\
\hline savanna & & & & & & \\
\hline Total percentage $\mathrm{e}^{b}$ & 99.1 & 99.8 & 99.8 & 99.8 & 99.9 & 99.8 \\
\hline
\end{tabular}

\footnotetext{
${ }^{a}$ In each column, percentage values for the three most abundant biogeographical groups represent their proportional contribution to total mean abundance per trap (see Table 1 ).

${ }^{b}$ In most cases, totals do not equal $100 \%$ because no data are included for widespread, upland (Highveld), and unclassified species.
}

Tswalu. The other 15 species were centered in the southwest arid region and, presumably, represented endemic species of the arid southwest sands or an edge effect across the Nama Karoo/Kalahari ecotone. At greater distance from this ecotone to the northeast, only 9 southwest arid species were represented in Tswalu compared with 27 in the southwest Kalahari and 33 in the entire area studied by Davis et al. (2008) that included large parts of the northern Nama Karoo. In terms of species abundance, there was $63.4 \%$ similarity (Steinhaus index $\times 100$ ) between the overall faunas of Tswalu attracted to pig dung and those of the southwest Kalahari attracted to mixed cattle and sheep dung baits (Steinhaus similarity is based on paired comparisons of proportional species abundance on a scale of $0-1$, see Legendre and Legendre 1983), despite differences in trapping protocol. Thus, the dung beetle assemblage in Tswalu would be highly representative of the characteristic regional biota.

Of the various local factors that might modify dung beetle assemblage structure across the landscape of Tswalu, prominent influences might be changes in edaphic character, vegetative physiognomy, or density of different dung types. Although vegetative physiognomy is mostly characterized by open grassland with limited tree cover, there is some increasing density of woody cover in the Monechma incanum shrubveld in the southwest. However, there is no consistent distancing of ordination data points for sites 3 and 4 from other plains and dunes sites in the southwest of Tswalu. There might also be some effects of localization in the distribution of different dung types such as that produced by the concentration of rhinoceros on the southwest plains. Such localizations could be particularly influential given the biases toward different bait types shown in the food association analysis. However, much of the variation seen in the reserve may be related to edaphic factors, which are recorded as differing between landscapes and vegetation communities (Van Rooyen et al. 2005).

Soil type influences dung beetles through the ease or difficulty with which it may be tunnelled (Hanski and Cambefort 1991), as well as by its varying water retention and drainage properties (Davis 2002), all of which are related to grain size, soil depth, soil chemistry, and inclusions such as humus content. Dryness in the rocky, shallow, sandy soils of the mountains, are probably a primary reason why the fauna of the mountains is dominated by dung beetle species characteristic of assemblages found in much more arid regions to the southwest. Rapid drainage and relative dryness in the central dune field may also be a reason for the absence of typical Kalahari dune grass species (Van Rooyen et al. 2005) and the greater proportional representation of southwest arid dung beetle elements compared with other dune or plains vegetation communities. Deep dune sands in the north clearly favor greater abundance in some species (Table 1), whereas differences in soil type between northern and southwest plains (Van Rooyen et al. 2005) may also have an effect. However, measurements of the physical characteristics of the soils need to be made for a more in depth analysis of how they might influence distributions of dung beetle species.

The overall reason for the separation into hills, northern, and southern centered clusters of species assemblages is unclear and may be related to a complex of factors, not all of them related to soil type. Ordination of species distributions across vegetation communities yielded a scatter of data points with no clear division into identifiable clusters. This is consistent with the observation that there are various different species distribution patterns. Most are difficult to interpret, even those that show a relatively consistent bias to northern dunes (Scarabaeus damarensis, Scarabaeus inoportunus, Proagoderus sappharinus), southwest plains (Scarabaeus zambesianus, Onthophagus sp. nr variegatus, Phalops rufosignatus), or eastern hills (Gymnopleurus humanus, Neosiyphus macroruber, Onthophagus sp. G). However, these trends on the hills, plains and dunes are, presumably, the origin of the overall north-south spatial bias shown in the analysis of species assemblage structure.

In conclusion, further study of the physical properties of the environment and the distributional centering of the diverse mammal fauna would assist in the 
interpretation of the spatial patterns shown by dung beetles in Tswalu. However, it is clear that the hills and northern and southern parts of Tswalu incorporate different qualities that diversify the dung beetle fauna of the reserve. It is unclear whether this fauna is entirely representative of that which existed before the local extinction and reintroduction of some large indigenous mammals because there is no point of reference. However, it does currently harbor a fauna that is comparable to other areas of the southern Kalahari that are farmed in an environmentally friendly manner (see Davis et al. 2008).

\section{Acknowledgments}

We thank the Tswalu Foundation, established by the Oppenheimer family, for the support of conservation research projects in Tswalu Kalahari Reserve and for funding and D. MacFadyen for providing daily rainfall data recorded in Tswalu during 2006-2008.

\section{References Cited}

Cambefort, Y. 1982. Les coléoptères Scarabaeidae s. str. de Lamto (Côte d'Ivoire): structure des peuplements et rôle dans l'écosystème. Ann. Soc. Entomol. Fr. 18: 433-459.

Colwell, R. K. 2005. EstimateS: statistical estimation of species richness and shared species from samples. Version 7.5. (http:// purl.oclc.org/estimates).

Davis, A.L.V. 1994. Associations of Afrotropical Coleoptera (Scarabaeidae, Aphodiidae, Staphylinidae, Hydrophilidae, Histeridae) with dung and decaying matter: implications for selection of fly-control agents for Australia. J. Nat. Hist. 28: 383-399.

Davis, A.L.V. 1995. Daily weather variation and temporal dynamics in an Afrotropical dung beetle community (Coleoptera: Scarabaeidae). Acta Oecol. 16: 641-656.

Davis, A.L.V. 1996. Habitat associations in a South African, summer rainfall, dung beetle community (Coleoptera: Scarabaeidae, Aphodiidae, Staphylinidae, Histeridae, Hydrophilidae). Pedobiologia 40: 260-280.

Davis, A.L.V. 1997. Climatic and biogeographical associations of southern African dung beetles (Coleoptera: Scarabaeidae s. str.). Afr. J. Ecol. 35: 10-38.

Davis, A.L.V. 2002. Dung beetle diversity in South Africa: influential factors, conservation status, data inadequacies and survey design. Afr. Entomol. 10: 53-65.

Davis, A.L.V., and C. F. Dewhurst. 1993. Climatic and biogeographical associations of Kenyan and north Tanzanian dung beetles (Coleoptera: Scarabaeidae). Afr. J. Ecol. 31: 290-306.
Davis, A.L.V., C. H. Scholtz, and C. Deschodt. 2008. Multiscale determinants of dung beetle assemblage structure across abiotic gradients of the Kalahari-Nama Karoo ecotone, South Africa. J. Biogeogr. 35: 1465-1480.

Doube, B. M. 1991. Dung beetles of southern Africa, pp. 133-155. In I. Hanski and Y. Cambefort (eds.), Dung beetle ecology. Princeton University Press, Princeton, NJ.

Excoffier, L., G. Laval, and S. Schneider. 2006. Arlequin ver. 3.1. An integrated software package for population genetics data analysis. (http:// cmpg.unibe.ch/software/ arlequin 3 )

Fincher, G. T., T. B. Stewart, and R. Davis. 1970. Attraction of coprophagous beetles to feces of various animals. J. Parasit. 56: 378-383.

Hanski, I., and Y. Cambefort. 1991. Competition in dung beetles, pp. 305-329. In I. Hanski and Y. Cambefort (eds.), Dung beetle ecology. Princeton University Press, Princeton, NJ.

Kirk, A. A., and T. J. Ridsdill-Smith. 1986. Dung beetle distribution patterns in the Iberian Peninsula. Entomophaga 31: 183-190.

Legendre, L., and P. Legendre. 1983. Numerical ecology. Elsevier, Amsterdam, The Netherlands.

Lobo, J. M., J. Hortal, and F. J. Cabrero-Sañudo. 2006. Regional and local influence of grazing activity on the diversity of a semi-arid dung beetle community. Divers. Distrib. 12: 111-123.

Mucina, L., and M. C. Rutherford (eds.). 2006. The vegetation of South Africa, Lesotho and Swaziland. Strelitzia 19: $1-807$.

Nealis, V. G. 1977. Habitat associations and community analysis of south Texas dung beetles (Coleoptera: Scarabaeinae). Can. J. Zool. 55: 138-147.

Peck, S. B., and H. F. Howden. 1984. Response of a dung beetle guild to different sizes of dung bait in a Panamanian rainforest. Biotropica 16: 235-238.

Statsoft. 2004. STATISTICA for Windows computer programme manual. Statsoft, Tulsa, OK.

Tshikae, B. P., C. H. Scholtz, and A.L.V. Davis. 2008. Trophic associations of a dung beetle assemblage (Scarabaeidae: Scarabaeinae) in a woodland savanna of Botswana. Environ. Entomol. 37: 431-441.

Tswalu Conservation Project. 2009. Assessment of the diversity and abundance of dung beetle on Tswalu Kalahari Reserve. (http://www.tswalu.com/index.php/thereserve/conservation-projects/P15/)

Van Rooyen, N., M. W. van Rooyen, and G. J. Bredenkamp. 2005. The vegetation types and veld condition of Tswalu Kalahari Reserve. (http://ecoport.org/ep? SearchType $=$ earticleView $\&$ earticleId $=696 \&$ page $=$ $-2)$.

Received 11 September 2009; accepted 23 February 2010 